\title{
GENERALIZED MINTY PREVARIATIONAL INEQUALITY, INVEX-INCREASE-ALONG-RAYS PROPERTY AND INVEX-STAR-SHAPED OPTIMIZATION PROBLEM
}

\begin{abstract}
RONG HU
Abstract. The purpose of this paper is to study some relations between generalized Minty prevariational inequalities, invex-increase-along-rays properties, and invex-star-shaped optimization problems. We introduce the concepts of invex-star-shaped sets and invex-increase-alongrays functions, and establish the relations between invex-increase-along-rays properties and invex-star-shaped optimization problems. Further, under certain conditions, we investigate the relations between invex-increase-along-rays properties and generalized Minty prevariational inequalities. As consequences, we obtain the equivalence of generalized Minty prevariational inequalities and invex-star-shaped optimization problems under suitable conditions. Finally, we prove the equivalence of generalized Minty prevariational inequalities and perturbed generalized Minty prevariational inequalities.
\end{abstract}

Mathematics subject classification (2010): 49J40, 90C26.

Keywords and phrases: Generalized prevariational inequality, invex-star-shaped set, invex-increasealong-rays property, invex radially lower semicontinuity, optimization problem, prequasiinvex function.

\section{REFERENCES}

[1] C. Baiocchi And A. CAPelo, Variational and Quasivariational Inequalities. Applications to FreeBoundary Problems, J. Wiley, New York, 1984.

[2] D. Kinderlehrer And G. Stampacchia, An Introduction to Variational Inequalities and their Applications, Academic Press, New York, 1980.

[3] R. W. Cottle, F. Giannessi and J. L. Lions (ed.), Variational Inequalities and Complementarity Problems, John Wiley\& Sons, Chichester, 1980.

[4] G. Is AC, Topological Methods in Complementarity Theory, Kluwer Academic Publishers, Dordrecht, 2000.

[5] G. J. Minty, On the generalization of a Direct method of the calculus of variations, Bull. Amer. Math. Soc. 73 (1967), 314-321.

[6] F. Giannessi, On Minty variational principle, in New Trends in Mathematical Programming, Edited by F. Giannessi, T. Rapcsák, and S. Komlósi, Kluwer Academic Publishers, Dordrecht, Netherlands (1998), 93-99.

[7] X. M. YAng, X. Q. YANG AND K. L. TeO, Some remarks on the Minty vector variational inequality, J. Optim. Theory Appl. 121 (2004), 193-201.

[8] G. P. CRespi, I. GincheV AND M. RocCA, Minty variational inequalities, increase-along-rays property and optimization, J. Optim. Theory Appl. 123 (2004), 479-496.

[9] G. P. CRESPI, I. GINCHEV, AND M. RocCA, Existence of solutions and star-shapedness in Minty variational inequalities, J. Global Optim. 32 (2005), 485-494.

[10] D. E. WARD AND G. M. LEE, On relations between vector optimization problems and vector variational inequalities, J. Optim. Theory Appl. 113 (2002), 583-596.

[11] J. PARIDA, M. SAhoo AND A. Kumar, A variational-like inequality problem, Bull. Austr. Math. Soc. 39 (1989), 223-231.

[12] X. Q. YANG AND G. Y. Chen, A class of nonconvex functions and pre-variational inequalities, J. Math. Anal. Appl. 169 (1992), 359-373. 
[13] X. M. YANG, On characterizing the solution sets of pseudoinvex extremum problems, J. Optim. Theory Appl. 140 (2009), 537-542.

[14] M. A. Hanson, On sufficiency of the Kuhn-Tucker conditions, J. Math. Anal. Appl. 80 (1981), 545550.

[15] S. K. Mishra And G. Giorgi, Invexity and Optimization, Springer, Berlin, 2008.

[16] J. C. YAO, A basic theorem of complementarity for the generalized variational-like inequality problem, J. Math. Anal. Appl. 158 (1991), 124-138.

[17] Q. H. ANSARI AND J. C. YAO, On nondifferentiable and nonconvex vector optimization problems, J. Optim. Theory Appl. 106 (2000), 475-488.

[18] Q. H. ANSARI AND J. C. YAO, Iterative schemes for solving mixed variational-like inequalities, J. Optim. Theory Appl. 108 (2001), 527-541.

[19] Y. P. FANG AND N. J. HUANG, Variational-like inequalities with generalized monotone mappings in Banach spaces, J. Optim. Theory Appl. 118 (2003), 327-338.

[20] X. Q. YAnG, On the gap functions of prevariational inequalities, J. Optim. Theory Appl. 116 (2003), 437-452.

[21] T. WeIR AND B. Mond, Pre-invex functions in multiple objective optimization, J. Math. Anal. Appl. 136 (1988), 29-38.

[22] T. WEIR AND V. JEYAKUMAR, A class of nonconvex functions and mathematical programming, Bull. Austr. Math. Soc. 38 (1988), 177-189.

[23] R. PINI, Invexity and generalized convexity, Optimization, Vol. 22 (1991), 513-525.

[24] S. R. Mohan And S. K. NeOgy, On invex sets and preinvex functions, J. Math. Anal. Appl. 189 (1995), 901-908.

[25] X. M. YANG, X. Q. YANG AND K. L. TeO, Characterizations and applications of prequasi-invex functions, J. Optim. Theory Appl. 110 (2001), 645-668.

[26] X. M. YANG, X. Q. YANG AND K. L. TEO, Generalized invexity and generalized invariant monotonicity, J. Optim. Theory Appl. 117 (2003), 607-625.

[27] A. Ben-Israel And B. Mond, What is invexity?, J. Austr. Math. Soc. Ser. B 28 (1986), 1-9.

[28] B. D. Craven, Invex functions and constrained local minima, Bull. Austr. Math. Soc. 24 (1981), 357-366.

[29] X. M. YAnG, X. Q. YANG AND K. L. TeO, Criteria for generalized invex monotonicities, European J. Oper. Res. 164 (2005), 115-119.

[30] J. CHUDZIAK AND J. TABOR, Characterization of a condition related to a class of preinvex functions, Nonlinear Anal. 74 (2011) 5572-5577.

[31] P. H. SaCh AND J. P. Penot, Characterizations of generalized convexities via generalized directional derivatives, Numer. Funct. Anal. Optim. 19 (1998), 615-634. 